\title{
ULUSLARARASI ÖĞRENCİLERİN AKADEMİK VE SOSYAL YAŞAMLARINDA KARŞILAŞTIKLARI SORUNLAR ÜZERİNE İNCELEME
}

\author{
Fikret TOPAL ${ }^{*}$ \\ Soner TAUSCHER ${ }^{* *}$
}

Öz

Küreselleşme sürecinin sağladığı ivmeyle birlikte son yıllarda uluslararası öğrenci hareketliliğinde ciddi bir artış olduğu gözlemlenmektedir. Genellikle İngilizce konuşulan ülkelere gerçekleșen bu hareketlilik ev sahibi ülkelere hem ekonomik hem de kültürel birçok alanda katkı sağlamaktadır. Böylece uluslararası öğrenci hareketliliği ülkeler için ilgi çekici olmakta ve buna ilişkin politikalar üretilmektedir. Türkiye de bu bağlamda son yıllarda uluslararası öğrenci hareketliliğinin artış sağladığı ülkeler arasında yer almaktadır. Buna göre bu çalışma öncelikle dünyada uluslararası öğrenci hareketliliğini açıklamaktadır. Daha sonra Türkiye'de ve Sakarya Üniversitesi özelinde uluslararası öğrencilerin hareketliliğini incelemektedir. Çalışmanın ikinci kısmında uluslararası öğrencilerin sorunlarına ilişkin literatür analiz edilerek bu sorunların hangi bağlamlarda tartışıldığı ortaya konulmaktadır. Bu çalışmada sorunlar iki başlık altında toplanarak eğitim (akademik) ve sosyo-ekonomik (sosyal yaşam) sorunlar bağlamlarında değerlendirilmektedir. Çalışmada veri toplama tekniği olarak yüz yüze anket yöntemi kullanılmıştır. SPSS analizi sonrası C\&A değeri 0,817 çıkmıştır. Bulgular arasında oryantasyon eksikliği, iletişim eksikliği, eğitimin niteliğine dair endişe, ekonomik durum ve sıla hasreti gibi sorunlar bulunmaktadır

Anahtar Kelimeler: Göç, eğitim, uluslararası öğrenciler, akademik sorunlar, sosyal sorunlar

\footnotetext{
*Araş. Gör., Sakarya Üniversitesi, fikrettopal@sakarya.edu.tr, ORCID: 0000-00017579-0017

**Araş.Gör., Sakarya Üniversitesi, sonert@sakarya.edu.tr, ORCID: 0000-0003-18375831
}

DOI: $10.17550 /$ akademikincelemeler.624380 


\title{
A Study on the Problems of International Students in the Academic and Social Life
}

\begin{abstract}
With the momentum provided by the globalization process, it has been observed that there has been a substantial increase in international student mobility in recent years. The mobility, mostly occurring towards the English speaking countries, contributes to host countries in many ways particularly economic and culturally. Thus, international student mobility is interesting for countries and policies are produced about that. In this context, Turkey in recent years rank among these countries which international student mobility increased. Accordingly, the study primarily explains international students mobility in the world. Then it examines the international student mobility in Turkey by taking Sakarya University as case study. In the second part of the work, by analyzing the literature on international students' problems, it has been revealed that in which context the problems being discussed. In this study, the problems are gathered under two titles and evaluated in the context of education (academic) and socioeconomic (social life) problems. This study used face to face survey method as data collection technique. After SPSS analysis, C\&A value was found as 0,817. Findings include problems such as; lack of orientation and communication, concerns about the quality of education, economic situation and homesickness.
\end{abstract}

Keywords: Migration, education, international students, academic problems, social problems.

\section{Giriş: Dünyada ve Türkiye'de Uluslararasi Öğrenciler}

Son yıllarda küreselleşmenin ve onun getirdiği imkânların sağladı̆̆ı ivmeyle uluslararası öğrenci ${ }^{1}$ hareketliliğinde yükseliş

1 Literatürde, yabancı uyruklu öğrenci (foreign students), uluslararası öğrenci (international students) vb. kavramlar kullanılmaktadır. Yabancı uyruklu öğrenci kavramı daha çok vatandaşlık üzerinden yapılan bir tanımlamadır. Yabancı uyruklu öğrencilerin ülkelerin politika tercihlerine göre uzun dönemli ikamet sahibi hatta o ülkede doğmuş olma ihtimalleri bulunmaktadır. Uluslararası öğrenci kavramı ise eğitim amaçlı başka bir ülkeye giden öğrencileri anlatmaktadır (OECD, 2018, 225). $\mathrm{Bu}$ çalışmada da uluslararası öğrenci (international students) kavramı tercih edilmiştir. 
olduğu gözlemlenmektedir. 1999 yllında iki milyon olan uluslararası öğrenci sayısı 2016 yllına gelindiğinde beş milyona ulaşmıştır. Beş milyon uluslararası öğrencinin üç buçuk milyonu OECD bölgesinde bulunmaktadır (OECD, 2018, 219). OECD bölgesinde en çok öğrenci çeken ülkeyse Amerika Birleşik Devletleri'dir (ABD). 3.5 milyon öğrenci içerisinde 971 bin öğrenci ABD'de bulunmaktadır. Genellikle İngilizce konuşulan ülkeler bu bağlamda ilk sırayı almaktadır. Öğrenci hareketliliğinin yarısından fazlası İngilizce konuşan 4 ülkeye olmaktadır. ABD'den sonra Birleşik Krallık 432 bin ile ikinci, Avustralya 336 bin ile üçüncü, Kanada ise 189 bin ile dördüncü sırayı almaktadır. Bu ülkelerdeki öğrencilerin büyük kısmınıysa Asyalı öğrenciler oluşturmaktadır. Avustralya'daki öğrencilerin \%87'si Asyalı iken, ABD'nin \%77'si, Kanada'nın \%61'i, Birleşik Krallık'ın ise \%52'sini oluşturmaktadır (OECD, 2018, 221). 2017-2018 verilerine göre ise ABD'de 1.094.792 uluslararası öğrenci bulunmaktadır. Bu öğrenciler de ABD içerisindeki yükseköğrenimin \%5,5'ini oluşturmaktadır (Open Doors, 2018). Nitekim Hobsons'un 2017 yılında yaptığı çalışmada da öğrencilerin "en güvenli ülke", "en iyi eğitim kalitesine sahip ülke", "en misafirperver ülke", "en iyi yaşam tarzına sahip ülke", "en iyi parasal imkânlar sağlayan ülke" gibi sorulara verdikleri cevaplara bakıldığında, ABD, Avusturalya, Kanada, Birleşik Krallık gibi ülkeler ilk sıraları paylaşmaktadır.

Yükseköğretimde uluslararası öğrencilerin artan etkinliği hem üniversitelere hem de ilgili ülkeye ekonomik, kültürel ve sosyal birçok bağlamda katkı sağlamaktadır. Örneğin uluslararası öğrencilerin Amerikan ekonomisine katkısı 2017 itibariyle 42 milyar dolardır (Open Doors, 2018). Bu bağlamıyla uluslararası öğrenci hareketliliğinin ekonomik boyutu ev sahibi ülkelerin ilgisini çekmektedir ve bu öğrencilere yönelik politikalar geliştirmektedirler. Ayrıca bu hareketliliğin uluslararası öğrenci çeken ülkeler açısından en avantajlı taraflarından biri de nitelikli insan dolaşımını sağlamasıdır. Ev sahibi ülkeler kaynak ülkenin yetişmiş, nitelikli 
öğrencilerini kendi bünyelerine katabilmektedir.

OECD bölgesinde yükseköğretim programlarına kayıt olan öğrenciler arasında Asya'dan gelen öğrenciler 1.9 milyon ile en fazla grubu oluşturmaktadır. Bunların 860 bini Çin'den gelmektedir. İkinci en büyük grup ise 845 bin ile Avrupalılardır. Bu öğrencilerin \%80'i de hareketliliğini Avrupa içerisinde gerçekleştirmektedir. Bu durum büyük oranda Erasmus programı ile açıklanmaktadır. Afrika ve iki Amerika kıtası ise OECD ülkelerine yaklaşık 300 bin öğrenci göndermektedir. Afrikalı öğrencilerin 3/4'ü Avrupa'yı tercih etmektedir (\%35 Fransa, \%12 Birleşik Krallık, \%7'si ise Almanya). Latin Amerikalı öğrencilerin İspanya'yı, Kuzey Amerikalı öğrencilerin ise Birleşik Krallığı tercih ettikleri de görülmektedir (OECD, 2018, 221).

Uluslararası öğrenci hareketliliğinde kültürel, tarihsel ve dilsel bağların etkili olduğu Latin Amerikalı öğrencilerin İspanya'yı ve Kuzey Amerikadaki öğrencilerin Birleşik Krallık'ı seçmesinde görülebilir. Bu bağların yanında ev sahibi ülkedeki ekonomik şartlar, döviz kurundaki değişim, daha karşılanabilir eğitim maliyetleri, düşük öğrenim ücretleri veya yükseköğretim sübvansiyonları gibi ekonomik faktörler de öğrenci hareketliliğinde önemli rol oynamaktadır (OECD, 2018, 223). ABD başkanı Trump'ın uyguladığı seyahat yasağ ${ }^{2}$ sonrası 1030 kişiyle yapılan bir anket çalışmasında öğrencilerin \%61'inin karar sonrası Amerika'da okumak konusunda endișeli olduğu görülmektedir (Hobsons, 2017, 13). Bu örnek, politik gelişmelerin de öğrencilerin tercihleri üzerindeki etkisini göstermesi açısından önemlidir. Yine Hobsons $(2017,5)$ tarafından dünya ölçeğinde 65 üniversitenin ve 62 bin civarı öğrencinin katılımıyla gerçekleştirilen uluslararası öğrenciler anketinde, öğrencilerin

\footnotetext{
2 ABD Başkanı Trump tarafından 2017 yılında başkanlık kararnamesi ile ilan edilen seyahat yasağı uygulaması Irak, Suriye, İran, Libya, Somali, Sudan ve Yemen gibi Müslüman ülkeleri kapsamaktadır. Bu yüzden yasak "Müslüman Yasağı" (Muslims Ban) olarak da bilinmektedir. Daha ayrıntılı bilgi için bkz: (travel.state.gov).
} 
\%79'u üniversite seçiminde eğitim-öğretim kalitesinin önemini vurgulamaktadır. Bunun yanında güvenlik, misafirperver bir ortamın varlığı ve ekonomik olarak uygun olma durumu öğrencilerin gidecekleri yeri belirleme kriterleri arasında başta gelmektedir. Çetinsaya'ya göre de $(2014,145)$ kaynak ülkenin altyapı ve kapasite yetersizliği ile ev sahibi ülkenin "uluslararası alandaki imajı, sembolik değeri ve yükseköğretim alanında sunduğu sürdürülebilir öğrenim ve araştırma imkânları" gibi yükseköğretimde uluslararasılaşma sürecini besleyen iki boyut bulunmaktadır. McMahon (1992, 467-468) uluslararası eğitimin eşit olmayan ekonomik, kültürel ve politik ilişkilerin temel karakteristiğini oluşturduğu küresel bir sistemin içerisinde gerçekleştiğini dile getirerek uluslararasılaşma sürecini öğrencileri uluslararası eğitime kaynak ülkeden iten ("push") ve ev sahibi ülkeye çeken ("pull") faktörler olarak incelemiştir. Kondakçı da (2011, 577-578) uluslararası öğrencilerin yurtdışında eğitimini "gidiş̧ öncesi bireysel/kamusal ve gidiş sonrası bireysel/kamusal" gerekçeleriyle iki boyutta inceler. Öğrencinin kendi ülkesindeki olumsuz şartlar ve ev sahibi ülkedeki olumlu şartlar gidiş öncesi kamusal gerekçelerden biridir. Öğrencinin bireysel tercihleri, motivasyonu, beğenileri, öncelikleri gibi sebepler yine gidiş öncesi bireysel gerekçeleri oluşturmaktadır. Gidiş sonrası kamusal ve bireysel gerekçeler ise ev sahibi ülkedeki ağlar, organizasyonlar ve kültürel, ekonomik ve sosyal nedenlerle birlikte, öğrencilerin ev sahibi ülkedeki bireysel deneyimlerini de kapsamaktadır.

Uluslararası öğrencilerin Türkiye'yi tercih sebeplerine ilişkin çalışmasında Kondakçı $(2011,588)$, kaliteli akademik kurumların varlığının, farklı kültürleri keşfetme isteğinin, Türkiye'nin jeopolitik konumunun ve tarihsel mirasının uluslararası eğitimde Türkiye'yi cazip kılan faktörler arasında yer aldığını belirtmektedir. Ayrıca Kondakçı'nın çalışması farklı ülkelerden/bölgelerden gelen öğrencilerin farklı tercih sebepleri olduğunu göstermiştir. Örneğin 
Avrupa ve Amerika'dan gelen öğrenciler için temel motivasyon farklı kültürü keşfetme arzusu iken, Balkan ülkelerinden gelen öğrencilerin motivasyonunu akademik kalite oluşturmaktadır. Özoğlu vd. (2015) tarafından 37 uluslararası öğrenciyle yapılan nitel araştırmada da uluslararası öğrencilerin Türkiye’yi tercihinde etkili olan faktörler; eğitim kalitesi, eğitim ve hayat harcamalarının karşılanabilirliği, burs imkânları, kültürel-dini-etnik vb. yakınlıklar ve daha önce Türkiye'ye gelmiş arkadaş, akraba gibi yakınların tavsiyesi şeklindedir.

Görüldüğü gibi uluslararası öğrenci hareketliliğinin temel sebepleri arasında; kültürel, dilsel ve tarihsel bağlar, ekonomik şartlar, politik gelişmeler, kaynak ülkenin yetersizliği, ev sahibi ülkenin imajı ve sunduğu araștırma imkânları, bireysel ve kamusal birçok gerekçe bulunmaktadır. Burada özellikle kültürel, tarihsel ve dilsel bağların (İspanya ve Birleşik Krallık örneğinde de görüldüğü gibi) ve jeopolitik konumun Türkiye'deki hareketliliği açıklamada daha etkili olduğu iddia edilebilir. Ayrıca 2011 yılından itibaren artarak devam eden Suriye İç Savaşı zorunlu olarak bir göç hareketi doğurmaktadır. İç savaştan kaçan Suriye kökenli üniversite öğrencileri de Türkiye'deki yabancı öğrenci sayısında önemli bir artışa neden olmaktadır. Tablo 1'e bakıldığında bu durum daha net bir şekilde görülmektedir.

YÖK, 2012 yılından itibaren Suriye'den Türkiye’ye göç eden üniversite öğrencilerin sorunlarını çözmek için girişimlerde bulunmaktadır. Bunun için öncelikle Suriye sınırında bulunan yedi üniversiteye resmi yazı göndererek Suriyeli mültecilerin özel öğrenci statüsünde üniversitelere kabul edilmelerini sağlamıştır. Bunun yanında Suriyeli sığınmacı öğrencilerden öğrenim ücreti alınmaması dair bir genelge yayınlamıştır (Seydi, 2014, 285, 287). Türkiye'de üniversite eğitimi alan Suriyeli öğrenci sayısını etkileyen faktörler arasında iç savaşın doğurdu koşullar ve YÖK'ün düzenlemeleri yanında Osmaniye Korkut Ata Üniversitesi'nde yapılan bir saha çalışmasının da gösterdiği üzere Suriyeli gençlere Türkiye'deki eğitim 
Uluslararası Öğrencilerin Akademik ve Sosyal Yaşamlarında Karşılaştıkları

Sorunlar Üzerine İnceleme

sistemi de cazip gelmektedir (Sezgin-Yolcu, 2016, 433).

Tablo 1: Uluslararası Öğrencilerin Uyruklarına Göre
Sayıları (2017-2018)

\begin{tabular}{|l|l|l|l|l|l|}
\hline Sıra & Ülke & $\begin{array}{l}\text { Öğrenci } \\
\text { Sayısı }\end{array}$ & Sıra & Ülke & $\begin{array}{l}\text { Öğrenci } \\
\text { Sayısı }\end{array}$ \\
\hline $\mathbf{1}$ & Suriye & 20.701 & $\mathbf{6}$ & Irak & 5.187 \\
\hline $\mathbf{2}$ & Azerbaycan & 17.088 & $\mathbf{7}$ & Almanya & 4.012 \\
\hline $\mathbf{3}$ & Türkmenistan & 12.247 & $\mathbf{8}$ & Bulgaristan & 2.510 \\
\hline $\mathbf{4}$ & İran & 6.418 & $\mathbf{9}$ & Çin & 2.084 \\
\hline $\mathbf{5}$ & Afganistan & 5.826 & $\mathbf{1 0}$ & Kazakistan & 2.065 \\
\hline
\end{tabular}

Kaynak: Yükseköğretim Bilgi Yönetim Sistemi, 2017-2018 Öğretim Yllı Yükseköğretim İstatistiklerinden derlenmiștir.

Son yıllarda her ne kadar uluslararası öğrenci sayısında lider olsa da ABD'de yeni kayıt yaptıran uluslararası öğrencilerin sayısı azalmaktadır (Open Doors, 2018). Dünya genelinde uluslararası öğrenci sayısının artmasıyla birlikte de ABD, Birleşik Krallık, Almanya, Fransa, Avustralya gibi geleneksel rotalar Rusya, Çin, Singapur, Malezya gibi yeni ülkelerle rekabete girmektedir (De Wit vd., 2013, 17). Uzun yıllar yükseköğretim için yurtdışına öğrenci gönderen kaynak ülke pozisyonunda olan Türkiye de son yıllarda uluslararası öğrencileri çekmek için çabasını artırmaktadır (Özoğlu vd., 2015, 224). Türkiye'de 1983'te 5.378 olan uluslararası öğrenci sayısı, 1990'da 7.661'e, 2000'de 16.656'ya, 2014'te 55.000'e yükselmiştir (Çetinsaya, 2014, 151). YÖK 2017-2018 yükseköğretim verilerine göre ise Türkiye'de toplam 125.138 uluslararası öğrenci bulunmaktadır. Bu öğrencilerin 81.783'ü erkek, 43.355'i ise kadınlardan oluşmaktadır. Öğrencilerin 8.600'ü önlisans 89.381'i lisans, 19.127'si yüksek lisans ve 8.030'u doktora yapmaktadır. Ancak bu artışa rağmen uluslararası öğrencilerin Türkiye'deki toplam öğrencilere oranı ABD ile kıyaslanıldığında hala düşük 
seviyededir. 2017-2018 verilerine göre bu oran \%1.65'dir.

Türkiye'yi tercih eden öğrencilerin üniversiteler arası dağılımına bakıldığında ise İstanbul Üniversite'sinin ilk sırayı aldığı görülmektedir. İlk 10 siraya bakıldığında (Tablo 2) Sakarya Üniversitesi'nin 2017-2018 YÖK verilerine göre en çok uluslararası öğrenciye sahip üniversiteler sıralamasında sekizinci sırada olduğu görülmektedir.

Tablo 2: Uluslararası Öğrencilerin Eğitim Birimlerine Göre Dağılımı (2017-2018)

\begin{tabular}{|l|l|l|l|l|l|}
\hline Sıra & Üniversite & $\begin{array}{l}\text { Öğrenci } \\
\text { Sayısı }\end{array}$ & Sıra & Üniversite & $\begin{array}{l}\text { Öğrenci } \\
\text { Sayısı }\end{array}$ \\
\hline $\mathbf{1}$ & İstanbul Üni. & 7.448 & $\mathbf{6}$ & Karabük Üni. & 3.329 \\
\hline $\mathbf{2}$ & Anadolu Üni. & 5.721 & $\mathbf{7}$ & $\begin{array}{l}\text { Ondokuz } \\
\text { Mayıs Üni. }\end{array}$ & 3.162 \\
\hline $\mathbf{3}$ & Uludağ Üni. & 4.356 & $\mathbf{8}$ & Sakarya Üni. & 3.151 \\
\hline $\mathbf{4}$ & Gaziantep Üni. & 3.175 & $\mathbf{9}$ & Mersin Üni. & 2.899 \\
\hline $\mathbf{5}$ & $\begin{array}{l}\text { İstanbul Aydın } \\
\text { Üni. (V.) }\end{array}$ & 3.505 & $\mathbf{1 0}$ & $\begin{array}{l}\text { Bahçeşehir } \\
\text { Üni. (V.) }\end{array}$ & 2.827 \\
\hline
\end{tabular}

Kaynak: Yükseköğretim Bilgi Yönetim Sistemi, 2017-2018 Öğretim Yılı Yükseköğretim İstatistiklerinden derlenmiștir.

Sakarya Üniversitesi'nin internet sitesinde yayınlanan 2019 yılı verilerine bakıldığında ise toplam 2.603 uluslararası öğrenci olduğu görülmektedir. Görüldüğü üzere geçen yıllara oranla uluslararası öğrenci sayılarında bir düşüş yaşanmıştır. $\mathrm{Bu}$ düşüşün temel sebebinin Sakarya'da kurulan ikinci üniversite ile ilgili olduğu söylenebilir. Bu öğrenciler arasında uyruklara göre ilk beş sıra Tablo 3 'teki gibidir. Bu öğrenci dağılımı Tablo 1'deki ulusal dağılım ile de paralellik göstermektedir. 
Tablo 3: Sakarya Üniversitesindeki Uluslararası Öğrencilerin Uyruklarına Göre Dağılımı

\begin{tabular}{|l|l|l|}
\hline Sıra & Ülke & Öğrenci Sayısı \\
\hline 1 & Azerbaycan & 351 \\
\hline 2 & Türkmenistan & 279 \\
\hline 3 & Suriye & 216 \\
\hline 4 & Afganistan & 206 \\
\hline 5 & Endonezya & 153 \\
\hline
\end{tabular}

Kaynak: (SAU, 2019)

\section{Uluslararası Öğrencilerin Sorunları}

Uluslararası öğrencilere yönelik teorik çalışmaların zeminini uluslararası göç literatürünün oluşturduğu söylenilebilir. Uluslararası göçü açıklamada kullanılan faktörler uluslararası öğrencilere de uyarlanarak benzer sebeplerin etkili olduğu varsayımı yapılmaktadır. $\mathrm{Bu}$ bağlamda uluslararası öğrenciler literatürü uluslararası göçten bağımsız değildir. Ancak Güçlü’nün de belirttiği gibi $(1996,103)$ yabancı öğrencilerin yaşadığı uyum sorunlarına ilişskin çeşitli kuramsal modeller geliştirilmiştir. Oberg'in "kültür şoku kuramı”, Lysgaard'ın “U-Eğrisi Yaklaşımı”, Gullarhorn ve Gullahorn'un "W-Eğrisi Yaklaşımı", Selby ve Woods'un "V-Ĕgrisi Yaklaşımı" bu modeller arasında yer almaktadır.

Literatürde uluslararası öğrencilerin sorunlarını anlamaya yönelik birçok çalışma bulunmaktadır. Gebhard (2012), Amerika'daki öğrencilerin karşılaştığı problemleri ve bu problemlere karşı tutumlarını anlattıkları çalışmasında problemleri; akademik, sosyal ilişkiler ve duygusal olmak üzere üç grupta toplamıştır. Kusek (2015), Ohio'da yaptığı çalışmada yabancı öğrenciler ile yerel halk arasındaki ilişkiyi incelemiştir. DeVors (2017), Amerika'da öğrencilerin entegrasyon sırasında karşılaştığı sorunlara odaklanmıștır. Hellsten ve Prescott (2004), uluslararası öğrenciler ile akademisyenler arasındaki ilişkiye odaklanarak bunun eğitim 
kalitesine olan etkisini anlamaya çalışmıştır.

$\mathrm{Bu}$ araștırmaların yanında öğrencilerin sorunlarını ölçmeye yönelik çeşitli ölçekler de geliştirilmiștir. Porter'ın “Michigan Yabancı Ögrrenci Problem Envanteri (Michigan International Student Problem Inventory)" ve Crano ve Crano'nun "The Inventory of Student Adjustment Strain (ISAS)" (1993) adlı ölçekleri bunlar arasında öncü sayılabilir. Ancak Crano ve Crano (1993, 271) bazı sorularını Michigan envanterinden uyarladı̆̆ını söylemektedir. Michigan Envanteri ise 1962 yllında Porter tarafından geliştirilmiş ve 1977 yllında revize edilerek son halini almıştır. 132 sorudan oluşan bu envanter 11 alt kategoriye ayrılmıştır (Can, 2015, 87). Porter, bu envanterin yabancı öğrenciler için geliştirildiğini ve kültürel olarak bağımsız olduğunu dile getirmektedir (Güçlü, 1996, 105). Uluslararası öğrencilerin sorunlarına yönelik uluslararası literatüre bakıldığında Michigan Envanterinin birçok araştırmacı tarafından da kullanıldığı görülmektedir. Galloway ve Jenkins (2005), Wang (2009), Malaklolunthu ve Selan (2011) gibi yazarlar uluslararası öğrenciler üzerine yaptıkları çalışmalarda bu envanteri kullanmışlardır. Güçlü de (1996) Pittsburgh Üniversitesi'nde yabancı öğrencilerin uyumuna ilişkin problemleri ve bunlara ilişkin öğrencilerin geliştirdiği stratejileri ve yardım kaynaklarını Michigan envanterini kullanarak araştırmıştır. Sadece bu envanter değil bunun yanında açık uçlu sorular da kullanılmıştır. Envanterin belirlediği 11 problem alanının da ölçüldüğü çalışmada öğrenciler en fazla zorluğu "İngilizce", daha sonra ise "mali yardım" alanında çektiklerini dile getirmişlerdir (Güçlü, 1996, 105). Ayrıca Güçlü, öğrencilerin ırk ayrımı, önyargı, stres, yalnızlık, memleket hasreti ve arkadaş edinme gibi alanlarda kişisel-toplumsal olarak zorluklar yaşadığını da ifade etmektedir. Nihayetinde Güçlü, bu sorunların aşılması için oryantasyon programının yaygınlaştırılması, yabancı öğrencilerin evlere konuk olarak alınması ve yabancı öğrenci hizmetleri merkezi gibi kurumların kültürlerarası danışmanlık hizmeti sağlaması gibi çözüm önerileri sunmaktadır (1996,108-109). 
Türkiye'de de uluslararası öğrenci literatürüne bakıldığında Michigan envanterinin uyarlanmasıyla yapılan çalışmalar olduğu görülmektedir. Kılıçlar vd. (2012) Türk dünyasından gelen turizm öğrencileri üzerine yaptıkları çalışmada bu envanteri kullanmış ve buna istinaden yeni bir ölçek geliştirmeye çalışmıştır. Kumcağız vd. (2016) de geliştirilen bu ölçeği kullanarak Ondokuz Mayıs Üniversitesi'ndeki uluslararası öğrencilerin yaşadığı sorunları sınıf düzeyine göre tespit etmeye çalışmıştır.

Türkiye'de bu ölçeğin dışında üniversite düzeyinde uluslararası öğrencilerin sosyo-kültürel ve uyum sorunları üzerine yapılan çeşitli çalışmaların ve geniş bir literatürün olduğu görülmektedir. Örneğin Özoğlu vd. (2015) tarafından yapılan çalışmada öğrencilerin Türkiye'de karşılaştığı problemler tespit edilmiştir. Bunlar; başvuru sürecinde, vize ve kayıt sürecinde, akademik hayatta ve sosyal hayatta yaşanan sorunlar şeklindedir. Çalışmanın sonuçları uluslararası öğrencilerin başvuru ve kayıt sürecinde yeterince bilgilendirilmediğini ve bazı öğretim görevlileri ile uluslararası öğrenciler arasında sorunlar yaşandığını göstermektedir. Alagöz ve Geçkil'in (2017) Konya ili özelinde 109 kişiyle yaptıkları anket çalışmasında yabancı öğrencilerin yaşadığı sorunlar incelenmiştir. Yabancı öğrencilerin yaşadığı sorunların başında Türkçeyi konuşma ve anlama sorunu gelmektedir. Katılımcılar sözel dersleri anlamada güçlük çektiklerini belirtmişlerdir. Bunun yanında "yemekler, lise denklik sorunlarl, dersleri anlama, sosyal yaşama uyum, ikamet izinleri ve sağlı hizmetlerinden yararlanma sorunları" (Alagöz ve Geçkil, 2017, 284) gibi sorunların Türkçe sorununu takip ettiğini belirtmiştir. Ayrıca yine aynı çalışmada öğrencilerin toplum içerisinde ayrımcılığa maruz kalma oranlarının çok az olduğu görülmektedir. Yabancı öğrencilerin \%15,6'sının öğrenci arkadaşlarından, \%6,4'ünün akademik personelden, \%4,6'sının idari personelden, \%23,9'unun ise halktan ayrımcllk gördüğü tespit edilmiştir. Ancak burada halktan görülen ayrımcıllk oranının görece 
yüksek olduğu vurgulanmalıdır. Bu bağlamda yabancı öğrencilerin halk ile ilişkisi noktasında yeni çalışmaların gerekliliği de ortaya çıkmaktadır. ${ }^{3}$

Uluslararası Öğrencilere ilişkin Sakarya Üniversitesi özelinde de çeşitli çalışmalar yapılmıştır. Örneğin Gürbüz ve Güleç (2016) tarafından Sakarya Üniversitesi'nde yapılan nitel araştırmada uluslararası öğrencilerin Türkçeye yönelik algıları ve dil öğrenme sürecinde yaşadığı sorunlar araştırılmıştır. Çalışmada Türkçe'nin yapısının ve dilbilgisi kurallarının zorlayıcılı̆ğ ortaya konulmuştur. Yardımcıoğlu vd. (2017) tarafından yapılan çalışmada yine Sakarya Üniversitesi'nde uluslararası öğrencilerin sosyo-ekonomik problemleri tespit edilmeye çalışılmıştır. Anket ve mülakat tekniğinin beraber kullanıldığı çalışmada uluslararası öğrencilerin ekonomik, psikolojik ve akademik sorunları olduğu hipotezleri doğrulanmıştır. Bunun yanında dil ve iletişim, arkadaşlık, sağlık, kültürel, sosyal sorunlar bağlamında sorunları olduğu hipotezleri doğrulanamamıştır. Ancak çalışmada iki farklı araştırma yönteminin kullanılması iki farklı sonucun ortaya çıkmasına yol açmıştır. Örneğin anket araştırmasının arkadaşlık sorunları başlığında uluslararası öğrencilerin “\%68.6”sı Türk arkadaşlarının kendilerine karşı anlayışlı olduğunu, \%66'sı Türk arkadaşlarının kendilerine genellikle yardım ettiğini, \%64.9'u dil problemi yüzünden Türkler ile iletişim kurmakta zorlanmadığını" (Yardımcıoğlu vd., 2017, 223) söylerken, aynı çalışmanın mülakatlarda dikkat çeken noktalar kısmında uluslararası öğrencilerin "hemen hemen tamamı Türk arkadaşlarının Türkçeleri dolayısıyla kendileriyle dalga geçtiğini bunun da konuşma motivasyonlarını düşürdüğünü konuşmaya korktuklarını ve çekindiklerini belirtmektedirler" (Yardımcıoğlu vd., 2017, 223) sonucuna varılmaktadır.

\footnotetext{
3 Burada bahsedilemeyen diğer çalışmalar için bkz: Paksoy vd. (2012), Sungur vd. (2016), Kıroğlu vd. (2010), Şahin ve Demirtaş (2014), Usta vd. (2017), Zavalsız ve Gündağ (2017), Gökyer (2017).
} 
Nihayetinde uluslararası öğrencilere ilişkin geniş bir literatürün varlığı yadsınamaz. Bu literatür üzerinden gidildiğinde sorunların eğitim ve sosyal yaşamla ilgili sorunlar olarak iki kategoride toplanabileceği söylenebilir. Nitekim bu çalışma da bahse konu olan çalışmalardan kapsam ve yöntem olarak farklılaşarak ve Michigan envanterinden uyarladığı soruları alt başlıklar halinde iki kategori etrafında toplayarak "akademik" ve "sosyal yaşama" dair sorunları tespit etmeye çalışmaktadır.

\section{Metodoloji}

Nicel araştırmalar anket veya yapılandırılmış mülakat gibi metotlar aracılığıyla geniş çaplı ölçümler yaparak istatistik üreten araştırmalardır (Dawson, 2007, 16). Bu çalışmalarda geçerli ve güvenilir ölçümler yapabilmek için örneklem temsiline dikkat edilmesi gerekmektedir. Punch'ın da dile getirdiği gibi $(2016,102)$ nicel araştırmalarda örneklemden toplanan veriler evren hakkında açıklamalar yapmak için gereklidir. Örneklemden toplanan bulgular evrene genellenmektedir. Bu yüzden örneklemin evreni temsil edip etmediği meselesi önem arz etmektedir. Bu çalışmanın örneklemini de rastlantısal seçim ile oluşturulmuş 368 kişi oluşturmaktadır. $\mathrm{Bu}$ kişilerin 193'ü $(\% 52,4)$ erkek ve 175'i $(\% 47,6)$ kadınlardan oluşmaktadır. Araştırmaya katılan öğrenciler Afrika, Asya, Balkanlar, Avrupa, Ortadoğu olmak üzere sınıflandırılmışlardır (Tablo 4). Sakarya Üniversitesi verilerine bakıldığında da Asya ve Afrika'dan gelen öğrencilerin oranlarının ortalama \%80'lere ulaştığı görülmektedir. 


\section{Tablo 4: Ankete Katılan Uluslararası Öğrencilerin Geldikleri Bölgeye Göre Dağılımı}

\begin{tabular}{|l|l|l|}
\hline Bölge & Frekans & Oranlar \\
\hline Afrika & 112 & 30,4 \\
\hline Asya & 188 & 51,1 \\
\hline Balkanlar & 22 & 6,0 \\
\hline Avrupa & 17 & 4,6 \\
\hline Ortadoğu & 24 & 6,5 \\
\hline Diğer & 5 & 1,4 \\
\hline Toplam & 368 & 100,0 \\
\hline
\end{tabular}

Araștırmanın evrenini Sakarya Üniversitesi'nde öğrenim gören uluslararası öğrenciler oluşturmaktadır. 2019 verilerine göre bu öğrencilerin sayısı 2.603'tür. Dolayısıyla +/- 0.05 örnekleme hatası için 2500-5000 kişi arası temsil sayısı 333 olduğundan (Yazıcıoğlu ve Erdoğan, 2004, 50) araştırma örneklemi evreni güvenilir bir şekilde temsil etme yeterliliğine sahiptir.

Çalışmada kültür farklılıklarından bağımsız olan ve geniş bir soru havuzunun bulunduğu Michigan Envanteri kullanılmıştır. Michigan Envanter'inde yer alan 11 konu başlığının hepsi anketin oluşturulmasında kullanılmıştır. Envanterin orijinalinde 132 soru yer almakla birlikte, bu çalışmada envanterin 59 sorusu araştırma için ehemmiyetine göre uyarlanarak kullanılmıştır. Bahse konu 11 başlık, akademik ve sosyal yaşam olmak üzere iki üst kategori altında toplanmıştır. Akademik kategori altında, seçme ve başvuru, oryantasyon, akademik sorunlar, dil ve eğitim konuları ele alınırken sosyal/kişisel sorunlar, yaşam ve yemek, sağllk hizmetleri, dini hizmetler, öğrenci aktiviteleri ve ekonomik sorunlar sosyal yaşam kategorisi altında değerlendirilmiştir. Bu iki kategori altında toplanan sorun alanları da birbirinden bağımsız değildir. Tam aksine birbiriyle ilişkili ve birbirlerini etkilemektedir. Sosyal yaşamda karşılaşılan güçlüklerin akademik hayata ve akademik hayatta yaşanılan sorunların sosyal hayata etkisi olmaktadır. 
Çalışmada veri toplama tekniği olarak yüz yüze anket tekniği kullanılmıştır. Demografik sorular kısmı belirli kategorilerden sadece birinin seçilebileceği kategori sorular şeklinde tasarlanmıştır. Sorunları tespit etmeye yönelik soruların bulunduğu ikinci kısımda ise yargı bildiren ifadelere katılımcıların katılıp katılmadığını belirten beşli Likert ölçeği kullanılmıştır. Sorular mümkün olduğunca sade bir dille ve kısa bir şekilde ifade edilmiştir. Her katılımcıya anketin amacı açıklanmış ve bilimsel amaçlar dışında kimseyle paylaşılmayacağı iletilmiştir. Sahaya çıkılmadan önce muhtemel hataları düzeltebilmek için pilot uygulama gerçekleştirilmiştir. Pilot uygulama sonrasında yanlış veya anlaşılamayan bazı ifadeler düzeltilmiş, katılımcıların cevap vermekten kaçındığı sorular çıkarılmış ve anket formu güncellenerek son halini almıştır. Anket verileri SPSS 22.0 programıyla analiz edilmiş, Cronbach's Alfa değerinin 0,817 olduğu görülmüştür.

\section{Bulgular}

Sakarya Üniversitesi'nde eğitim gören uluslararası öğrencilere dair demografik veriler, öğrencilerin sosyo-ekonomik arka planını ortaya koyması bakımından bulgulara temel teşkil edebilme kapasitesindedir. $\mathrm{Bu}$ bakımdan öğrencilerin ne kadar süredir Türkiye'de bulundukları, nerede ikamet ettikleri, temel geçim kaynaklarını nasıl sağladıkları, Türkçe dil seviyeleri ve nihayetinde Sakarya Üniversitesi'nden genel olarak memnun olup olmadıklarına dair araştırmanın demografik kısmını olușturan veriler önemlidir.

Araștırma grubunda bir ylldan az süredir Türkiye'de bulunanların oranı $\% 25,3$, bir-üç yıl arası $\% 43,5$, üç-beş yıl arası $\% 24,2$ ve beş yıldan fazla süredir Türkiye'de olanların oranı $\% 7,1$ 'dir. Görüldüğü üzere öğrencilerin önemli bir kısmını üç yıldan daha az süredir Türkiye'de kalanlar oluşturmaktadır. Bu durum lisansüstü eğitimde göz önüne alındığında uluslararası öğrencilerin bir süre daha Sakarya'da bulunacağına işaret etmektedir. Uluslararası 
öğrencilerin konaklama istatistiklerine bakıldığında \%54,1'nin KYK'da, \%19,8'inin özel yurtlarda ve \%23,6'sının da evde yaşadığı görülmektedir. Bunun yanında öğrenciler geçimlerini \%57,3 ile kamu, \%42,7 ile özel kaynaklardan karşılamaktadır. KYK ve kamu kaynaklarının kullanım oranı göstermektedir ki öğrencilerin Sakarya'daki eğitimleri büyük ölçüde kamu tarafından karşılanmaktadır. Öğrencilerin \%90,4'ü Türkçe diline B2, C1 ve C2 düzeyinde hâkim olduğunu beyan etmektedir. Bunun yanında Sakarya Üniversitesi'nden genel olarak memnuniyet oranı da \%92,7 ile oldukça yüksektir. Öğrencilerin sadece \%8,2'sinin mezuniyet sonrasında başka bir üniversiteye kayılt yaptırma düşüncesinde olması bu durumu doğrulayan bir diğer veriyi oluşturmaktadır. Öğrencilerin \%32,6'sı ise Sakarya Üniversitesi'nde kalıp lisansüstü çalışma yapmayı hedeflemektedir. Geri kalan öğrencilerin \%28'i memleketlerine dönmek istemektedir.

\subsection{Akademik Sorunlara Dair Bulgular}

Uluslararası öğrencilerin akademiye yönelik karşılaștıkları ilk sorun, ev sahibi ülkenin ve üniversitenin seçimi konusunda olmaktadır. Katılımcıların önemli bir oranının $(\% 70,9)$ Türkiye'de okumayı değerli bulması, öğrencilerin Türkiye'de bir üniversite eğitimi seçiminin bilinçli bir tercih olduğunu göstermektedir. Öğrencilerin görece az bir kısmının $(\% 27,2)$ vize ve oturum almada güçlük çekmesi Türkiye'deki yükseköğretimin seçilmesini cazip kılmaktadır. Türkiye'deki eğitimin cazibesi sadece seçme ve başvuru aşamasındaki kolaylıktan kaynaklanmamakta, öğrencilerin önemli bir kısmı ders planları $(\% 58,4)$ ve içerikleri $(\% 60,3)$ gibi kurumsal nitelikleri de olumlu karşılamaktadır. Ayrıca kurumsal olarak karşılaştıkları sorunların çözüm noktasında idari personeli başarılı bulmaktadır $(\% 72,2)$.

Üniversiteye başvuru ve kayıt sonrasında kurumu tanıtacak oryantasyon imkanları konusunda sorun görülmektedir. 
Katılımcıların sadece \%42,1'i oryantasyon almıştır. Bu oran geniş bir coğrafi alana yayılmış yaklaşık 50.000 öğrencisi bulunan bir üniversite için oldukça düşüktür. Buna rağmen öğrencilerin kampüste zaman geçirme olanakları $(\% 54,4)$ ve kütüphaneyi kullanma becerileri $(\% 69,9)$ noktasında olumlu bir durum bulunmaktadır. Bu durum, kampüs olanaklarına erişebilirliğin açık olması yanında, öğrencilerin sosyal girişkenliği ile yakından alakalıdır. Benzer bir sorun Taşar'ın Adıyaman Üniversitesi'ndeki Suriyeli öğrenciler üzerine yaptığı saha çalışmasında da görülmektedir. Suriyeli öğrencilerin dil yetersizliği akademik ve idari personelle olan iletişimde önemli sorunların doğmasına yol açmakta, öğrencilerin akademik ve idari işleyişe hâkim olmaması düşük not almalarına hatta derslerden kalmalarına yol açabilmektedir (Taşar, 2019, 170). Görüldüğü gibi oryantasyonun, akademik ve idari personelle ilişkilerin yetersiz olması uluslararası öğrencilerin akademik başarılarını doğrudan etkileyen unsurlardandır.

Her ne kadar Sakarya Üniversitesi on yıla yakındır uluslararası öğrenciler için cazip bir kurum olsa da halen öğrencilerin \%62,5'i kendisini yabancı öğrenci olarak hissetmektedir. Bu durum Sakarya Üniversitesi'nin yerelliğini koruduğunun bir göstergesi sayllabilir. Öğrencilerin \%34'nün üniversiteye ilk geldiklerinde kendi ülkeleri hakkında olumsuz düşüncelerle karşılaşması da bu durumu doğrular niteliktedir. Tüm bunlara rağmen yabancı öğrencilerin kendilerine karşı olumsuz bir algının olduğunu hissetme oranı \%16,3 ile oldukça düşüktür. Bunun yanında katılımcıların \%31,8'nin (Tablo 5) Türklerin öğrencilere karşı olumlu ya da olumsuz tutumu konusunda fikri olmaması, uluslararası öğrenciler ile Türkler arasındaki etkileşimde kısıtllılklar olduğunu göstermektedir ki çoğu soru da fikrim yok oranları görece yüksek çıkmaktadır. Uluslararası öğrencilerin Türkiye'deki ikamet süreleri arttıkça kendilerine karşı olan tutumlara yönelik algı pozitif yönde artmaktadır. Örneğin bir yıldan az kalanların kendilerine karşı Türklerin tutumlarını \%41,8 
gibi bir oranla olumlu bulurken, 1-3 yıl arasinda kalanlar \%51 ve 3-5 yıl arasında kalanlar \%64,1'lik oranlarla olumlu bulmaktadır.

Tablo 5: Türkiye'de Yabancı Öğrencilere Karşı Tutum Olumludur

\begin{tabular}{|l|l|l|}
\hline & Frekans & Oran \% \\
\hline Kesinlikle Katılmıyorum & 16 & 4,3 \\
\hline Katılmıyorum & 44 & 12,0 \\
\hline Fikrim yok & 117 & 31,8 \\
\hline Katılıyorum & 126 & 34,2 \\
\hline Kesinlikle Katılıyorum & 65 & 17,7 \\
\hline Toplam & 368 & 100,0 \\
\hline
\end{tabular}

Üniversiteye olan kurumsal adaptasyon sonrasında sorunların ortaya çıktığı diğer bir yer öğrencilerin eğitim/öğretim faaliyetleriyle ilişkilidir. Bunların başında derse katılımın zorunlu olmasından $\% 49,2$ 'si memnun ve \%46,4'ü de ders yükünün fazla olmasindan şikâyet etmektedir. Bu negatif tablonun karşısında ise öğrencilerin az bir kısmını teşkil eden \%21,5'i hocalarından yeterli yardımı alamadığını düşünmekte, söz konusu memurlardan yardım almak olduğu zaman bu oran \%19,3 ile daha da düşmektedir. Bu durum üniversitedeki insani ilişkilerin yüksek olmasının bir göstergesi iken, ders yükü, derse girme zorunluluğu gibi daha formel fenomenlerin öğrenciler için zorluk oluşturduğunu göstermektedir. 
Tablo 6: Uluslararası Öğrencilerin Dil Eğitimi ve Hâkimiyeti Konusundaki Verileri

\begin{tabular}{|c|c|c|c|c|c|}
\hline & 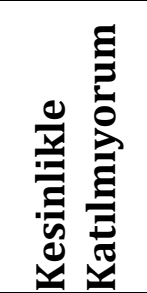 & 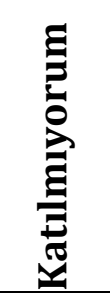 & 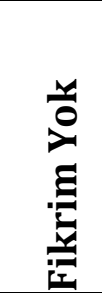 & 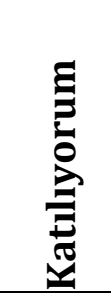 & 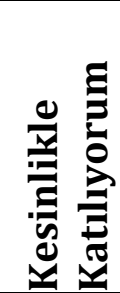 \\
\hline $\begin{array}{l}\text { TÖMER'den Aldığım } \\
\text { Türkçe Dersleri } \\
\text { Akademik Başarım İçin } \\
\text { Yeterlidir. }\end{array}$ & 17,4 & 19 & 16,8 & 33,2 & 13,6 \\
\hline $\begin{array}{l}\text { İhtiyaç Duyduğum } \\
\text { Zaman Türkçe } \\
\text { Konusunda TÖMER'den } \\
\text { Yardım Alabilirim }\end{array}$ & 5,7 & 15,8 & 22,6 & 41 & 14,9 \\
\hline $\begin{array}{l}\text { İyi Derecede Türkçe } \\
\text { Konuşurum }\end{array}$ & 6 & 19,8 & 16,8 & 42,7 & 14,7 \\
\hline $\begin{array}{l}\text { Türkçe Sunum } \\
\text { Yapabilirim }\end{array}$ & 6,3 & 18,2 & 19 & 41,6 & 14,9 \\
\hline $\begin{array}{l}\text { Türkçeyi Rahatça } \\
\text { Yazabilirim }\end{array}$ & 6,8 & 17,9 & 11,7 & 45,4 & 18,2 \\
\hline $\begin{array}{l}\text { Derslerimi Rahatça } \\
\text { Anlarım }\end{array}$ & 5,4 & 19,3 & 12 & 48,4 & 14,9 \\
\hline
\end{tabular}

Türkiye'ye gelen ve üniversitede bir yıl boyunca Türkçe hazırlık eğitimi alan uluslararası öğrencilerin \%46,8'i Türkçesinin akademik başarısı için yeterli olduğunu ve öğrencilerin \%55.9'u TÖMER'den yardım alabileceğini düşünmektedir. Bu noktada TÖMER'in eğitim sırasında ve sonrasında öğrencilerin beklentilerini karşılamadığı görülmektedir. Öğrencilerin dil yeterlilikleri entegrasyon ve uyum için en önemli alanlardan biridir. TÖMER'den daha yeterli çıkacak öğrencilerin sosyal ve akademik yaşamda yaşayabilecekleri sıkıntıların büyük bir kısmını daha kolay aşacağı söylenmelidir. Her ne kadar TÖMER beklentileri karşllamasa da öğrencilerin büyük kısmı kendini Türkçe konuşma, yazma, sunum yapma ve dersi 
anlama hususunda yeterli görmektedir. Bu durum da öğrencilerin kişisel çabaları ve sosyalleşme imkânları ile ilgilidir.

\section{Tablo 7: Uluslararası Öğrencilerin Dil Eğitimi ile Geldikleri Ülkelere Göre Çapraz Analizi}

\begin{tabular}{|c|c|c|c|c|c|}
\hline & $\underset{3}{2}$ & $\stackrel{\frac{\pi}{2}}{2}$ & $\frac{\bar{\pi}}{\tilde{\pi}}$ & $\underset{2}{2}$ & 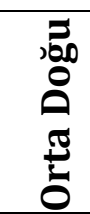 \\
\hline $\begin{array}{l}\text { TÖMER'den Aldığım Türkçe } \\
\text { Dersleri Akademik Başarım } \\
\text { İçin Yeterlidir. }\end{array}$ & 44,6 & 48,4 & 63,7 & 41,1 & 37,5 \\
\hline $\begin{array}{l}\text { İ́htiyaç Duyduğum Zaman } \\
\text { Türkçe Konusunda } \\
\text { TöMER'den Yardım } \\
\text { Alabilirim }\end{array}$ & 56,4 & 55,4 & 72,7 & 41,2 & 54,2 \\
\hline $\begin{array}{l}\text { İyi Derecede Türkçe } \\
\text { Konuşurum }\end{array}$ & 55,3 & 59,5 & 72,7 & 47 & 41 \\
\hline Türkçe Sunum Yapabilirim & 50 & 60,6 & 63,7 & 64,7 & 37,5 \\
\hline Türkçeyi Rahatça Yazabilirim & 62,5 & 66 & 86,4 & 64,7 & 37,5 \\
\hline Derslerimi Rahatça Anlarım & 58 & 66,5 & 72,7 & 64,7 & 54,2 \\
\hline
\end{tabular}

Uluslararası öğrencilerin geldikleri yer ile dil eğitimlerinin çapraz analizine bakıldığında dil yeterliliği konusunda öne çıkan iki grup bulunmaktadır. Balkan ülkeleri menşeili öğrenciler Türkçe dili konusunda konuşma, yazma, sunum yapma ve anlama becerilerinin oldukça yüksek olduğunu düşünürken, aksi yönde Orta Doğu ülkelerinden gelen öğrenciler bu yeteneklerinin daha kısıtlı olduğunu ifade etmektedir. Diğer bölgelerin bu yeteneklerinin de Orta Doğu'ya göre görece yüksek olduğu düşünüldüğünde bu durumun oluşmasındaki önemli gerekçelerden birini alfabenin farklı oluşuyla açıklamak mümkündür. Bunun yanında coğrafyada yaşanan iç savaş, çatışma ve terör olgusu, Orta Doğu'dan gelen öğrencilerin ciddi psikolojik sorun yaşamalarına sebebiyet vermekte, bu psikolojik sorunlar Türkçe öğrenimi, derslere katılım ve başarılı olmada önemli bir rol oynamaktadır. Örneğin; Harunoğulları vd., araştırmasının 
ortaya koyduğu üzere Suriye'den gelen öğrencilerin \%56'sının iç savaştan psikolojik olarak etkilendiği, \%20'sının sıla hasreti çektiği gözlemlenmektedir $(2019,826)$. Balkanlardan gelen öğrenciler dışındakiler aldıkları dil eğitimini akademik başarıları açısından çok yeterli görmemektedir. Bunun sebebinin Balkan kökenlilerin Türkçeyle diğer bölgelere nazaran daha fazla etkileşime girdikleri, böylece dile daha aşina oldukları söylenebilir.

Öğrencilerin büyük kısmının $(\% 70,9)$ Türkiye'de okumayı değerli bulmasına ve yukarıda da görüldüğü gibi Sakarya Üniversitesi'nden \%92'i ile memnun olmasına rağmen eğitim hususunda Türkiye'den ve Sakarya Üniversitesi'nden duyulan memnuniyetin az olduğu görülmektedir. \%31,8'lik önemli bir oran Türkiye'deki eğitimin bekledikleri gibi olmadığını belirtmişlerdir. Eğitimi olumlu bulanların oranı \%44,8'i geçmezken, kararsızların oranı \%23,4 ile oldukça yüksektir. Bu oranların Sakarya Üniversitesi ile diğer üniversiteler arasındaki farka dair fikirlerinin oldukça karmaşık olmasından kaynaklandığı söylenebilir. Çünkü öğrencilerin \%35,9'u imkânı olsa üniversitesini değiştireceğini dile getirirken $\% 27,7^{\prime}$ si de kararsızdır. Sadece \%37'lik kesim Sakarya Üniversitesi'nde eğitim görmekte kararlı bir tutum sergilemektedir. Bu veriler ders yükünden duyulan memnuniyetsizlik, kendini yabancı hissetme ve TÖMER eğitiminin yetersizliği ile beraber düşünüldüğünde sorunun akademik ve sosyal yanlarının belirleyiciliği görülmektedir. Ancak yine de öğrencilerin dil seviyelerini yüksek görmesi ve büyük oranda Türkçe sunum, yazma, konuşma ve anlama konusunda görece iyi olduklarını hissetmesi memnuniyetsizliğin niteliksel bir memnuniyetsizlik olabileceğini de göstermektedir. Öğrencilerin Türk yükseköğretim sistemi ve Sakarya Üniversitesi'nde okumaya dair sahip oldukları memnuniyetsizliğin diğer sebebini ise aldıkları eğitimin geldikleri ülkede iş bulmada artı bir rol oynayıp oynamayacağından emin olamamaları oluşturmaktadır. Öğrencilerin yarısı $(\% 50,6)$ Türkiye'de aldıkları 
eğitimin memleketlerine döndüklerinde iş bulmalarına katkı sağlayacağını düşünürken oldukça yüksek bir oran $(\% 33,2)$ bu konuda kararsızdır. Bu durum Türkiye'nin çok kısa bir süre önce dünyanın dört bir tarafından uluslararası öğrenci kabul etmesi sonucu mevcut mezunların ülkelerine dönmeleri ve iş deneyimlerinin oluşması sürecinin çok yeni olmasıyla ilişkili gözükmektedir. Aynı kararsızlık öğrencilerin çalışma imkânları bakımından kendi ülkeleri ile Türkiye arasında tercih yapmaları durumunda da gözükmektedir. Katılımcıların \%32,6'sı Türkiye'de çalışmaya olumlu bakarken $\% 28,5$ 'i kendi ülkesini tercih etmektedir. Olumlu ya da olumsuz görüşler görece dengeli bir seyir izlerken kararsızların oranı \%38,9 gibi yüksek bir yer kaplamaktadır. Öğrencilerin gerek kendi gerekse Türkiye'deki iş yaşamı ve çalışma olanaklarına dair yeterince bilgiye ve deneyime sahip olmamalarının böyle bir kararsızlığa yol açtı̆̆ düşünülebilir. Bu bakımdan yurtdışında öğrenim görmeyi düşünen yeni öğrenciler açısından Türkiye cazip bir ülke konumundayken üniversitede gördükleri eğitim, Türkiye'deki iş imkânları ve Türkiye'de aldıkları eğitimin gelecekteki iş bulma süreçleri açısından önemli bir deneyim ve bilgi eksikliği yarattığı düşünülmektedir. Üniversitelerin ve uluslararası öğrencilere burs vererek Türkiye'de okumalarına imkân veren kamu kurumlarının öğrencilere yönelik eğitim, öğretim ve gezi programlarının yanında onlara iş deneyimi kazandıracak staj olanaklarını sunması ve mezun bilgi sisteminin işler hale getirilmesi öğrencilerin mezuniyetten sonraki yaşamlarının şekillenmesinde önemli katkılar sunabilecektir.

\subsection{Sosyal Yaşam Sorunlarına Dair Bulgular}

Sadece uluslararası öğrenciler için değil aynı zamanda zorunlu göç ile gelen bir yabancı için de geldiği ülkede başarılı olabilmesinin yolu yaşadığı ortama asilime olmadan kendi değerlerini de koruyarak uyum sağlayabilmesinden geçmektedir. Yabancı bir ülkeye uyum sağlamada gelinen ülkenin dilinin, kültürünün ve sosyal hayatının öğrenilmesi kadar göçmen kabul eden ülkenin de gelen yabancılara 
karşı tutumu, toplumsal kabulü, yabancı kültürlere karşı açık olması gibi etkenler önemli rol oynamaktadır. Bu bakımdan anketin ikinci kısmını oluşturan sosyal yaşama dair sorunları olabildiğince doğru tespit edilebilmek adına sorular sosyal ve kişisel engeller, yaşam ve yemek, sağlık, dini inanç, diğer öğrencilerle sosyalleşme ve ekonomik sorunlar üst başlıkları altında katılımcılara yöneltilmiştir.

Tablo 8: Uluslararası Öğrencilerin Gündelik Yaşantısına

Dair Veriler

\begin{tabular}{|c|c|c|c|c|c|}
\hline & 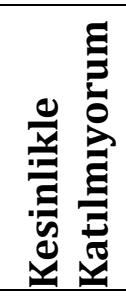 & 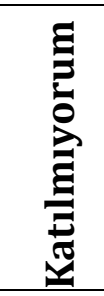 & $\begin{array}{l}y \\
\vdots \\
0 \\
0\end{array}$ & 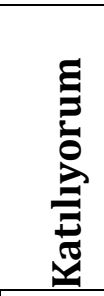 & 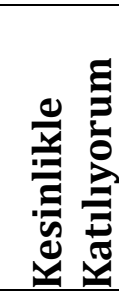 \\
\hline $\begin{array}{l}\text { Kalacak Yer Bulmada } \\
\text { Sorun Yașamadım }\end{array}$ & 9,0 & 20,7 & 11,1 & 40,2 & 19 \\
\hline $\begin{array}{l}\text { Kaldığım Yerden } \\
\text { Memnunum }\end{array}$ & 7,9 & 15,2 & 12 & 47,8 & 17,1 \\
\hline $\begin{array}{l}\text { Kaldığım Yerden } \\
\text { Üniversiteye Ulaşım } \\
\text { Kolaydır }\end{array}$ & 6,8 & 14,9 & 9,2 & 45,7 & 23,4 \\
\hline $\begin{array}{l}\text { Sağlık Sorunlarım } \\
\text { Bulunmaktadır }\end{array}$ & 19,6 & 35,6 & 16,8 & 22,3 & 5,7 \\
\hline $\begin{array}{l}\text { Sağlık Hizmetlerine } \\
\text { Ulaşmada Sorun Yaşamam }\end{array}$ & 9,2 & 16,6 & 22,3 & 42,4 & 9,5 \\
\hline $\begin{array}{l}\text { Üniversitenin Sunduğu } \\
\text { Sağllk Hizmeti Yeterlidir }\end{array}$ & 4,3 & 16,8 & 37,5 & 32,6 & 8,7 \\
\hline $\begin{array}{l}\text { Türkiye'de Okumak } \\
\text { Streslidir }\end{array}$ & 7,1 & 28,3 & 15,5 & 32,1 & 17,1 \\
\hline Türkler Misafirperverdir & 4,6 & 11,4 & 18,5 & 39,7 & 25,8 \\
\hline Türkiye'de Yaşam Ucuzdur & 15,5 & 32,9 & 16,3 & 27,7 & 7,6 \\
\hline $\begin{array}{l}\text { Türkiye'de Dinimi Rahatça } \\
\text { Yaşarım }\end{array}$ & 8,2 & 6 & 16,6 & 31,8 & 37,5 \\
\hline $\begin{array}{l}\text { İnancımdan Ötürü Bir } \\
\text { Ayrımcılığa Uğramadım }\end{array}$ & 7,1 & 10,6 & 24,7 & 28 & 29,6 \\
\hline
\end{tabular}


Uluslararası öğrencilerin sosyal yaşama dair verdikleri cevapların olumlu ve olumsuz istatistikleri bir önceki bölüme oranla daha fazla eşit dağılmıştır. Ayrıca kararsızlar/fikrim yok oranı akademik sorunlara dair verilen cevaplardan daha fazla gözlemlenmiştir. Bunun sebepleri arasında akademik yaşama dair yöneltilen soruların öğrencilerin yaşamında daha somut ve daimi karşılaştıkları problemleri ele almakla birlikte sosyal yaşamda bir sağlık ya da konut problemiyle her öğrencinin her an karşı karşıya kalmaması doğal olarak deneyimlemediği bir durum karşısında fikrinin bulunmaması yatmaktadır. Sosyal yaşam açısından iki önemli başlık olan ekonomi ve sosyalleşme ön plana çlkmaktadır. Sosyalleşmede yaşanılan sorunlar dini inanç, kültürel baskı ya da konut ve sağlı sorunları gibi altyapı problemlerinden oluşmamaktadır. Suriyeliler özelinde ise toplumsal kabulü etkileyen faktörler arasında kendilerinin ülkeden ve savaştan kaçtıkları, üniversiteye sınav kayıt yaptırabildikleri, yerli halkın işlerini elinden aldıkları vb. (Sezgin-Yolcu, 2016, 431) olumsuz önyargılar bulunmaktadir.

Katılımcıların sadece \%19,3'ü asimile olmaktan korkmaktadır. Bu oran bir yıldan az Türkiye'de bulunanlarda \%21,7 iken bir ila üç yıldır Türkiye'de bulunanlarda \%16,9'ye düşmektedir. Görüldüğü gibi üzerlerinde kültürel bir baskının bulunduğu öğrenci sayısı görece azdır. Dini yaşamın sürdürülebilmesi bakımından uluslararası öğrencilerin \%15,8'i ibadethaneye erişimde sorun yaşarken \%73,4'ü herhangi bir güçlükle karşılaşmamaktadır. Benzer oranlar dini inançları rahatça yaşayabilme imkânında da ortaya çıkmaktadır. Burada öğrencilerin \%15,2'si inançlarını serbestçe yaşayamadığını dile getirirken, \%69,3 inançlarını yaşamada bir sorunla karşılaşmadığını belirtmektedir. İnançlarından dolayı ayrımcılığa uğradığını düşünen öğrenci sayısı da son iki oranla görece paralellik arz ederek \%17,7 seviyesindedir. \%57,6 oranı dini inancı bakımından ayrımcılığa uğramadığını ifade etmektedir. $\mathrm{Bu}$ durum doğrudan uluslararası öğrencilerin önemli bir kısmının Müslüman 
ağırlıklı ülkelerden gelmeleri dolayısıyla kendilerinin Müslüman olmalarıyla yakından ilişkilidir. Dini inanca ayrımcılık konusunda toplum ile uluslararası öğrenciler arasında küçükte olsa bir gerilim olduğu göze çarpmaktadır. Benzer bir durum üniversitede yaşanılan dış görünüşe yönelik ayrımcllıkta da kendini göstermektedir. \%26,3 gibi önemli bir oran dış görünüşünden dolayı ayrımcllı̆a uğramaktadır. Bunlar arasında en yüksek oranı \% 28,6 ile Afrika ve \%27,6 ile Asya kökenliler oluștururken \% 17,7 ile Avrupa ve \% 16,7 Ortadoğu kökenliler ise en düşük oranları meydana getirmektedir. Bu durum genelde iki kültürün birbiriyle olan ilişkilerindeki önyargı ya da bilgisizlik kaynaklı olabilmektedir. Afrikalıların genelde ten rengi üzerinden ayrımcllı̆̆a uğramaları, Asya kökenlilerin ise göz yapılarından dolayı şakalara maruz kalmaları önemli gündelik ayrımcılık kategorileridir. Ancak oranların gösterdiği üzere sosyalleşme açısından önemli bir sorun oluşturmamakla beraber bu durum derin toplumsal ya da kültürel ırkçlıkla mı ilgili olduğu yoksa yabancı kültüre alışık olmamanın getirdiği iletişimsel nezaket yoksunluğundan mı kaynaklandığı araştırmaya muhtaç bir konudur.

Katılımcıların genç olmaları onların daha az sağlık sorunuyla karşılaşmasına yol açmaktadır. Öğrencilerin \%78'i sağlık sorunları bulunmadıklarını dile getirmektedir. Sağlı sorunları bulunanların $\% 21,1^{\prime} \mathrm{i}$ üniversitede mevcut sağlı hizmetlerine ve $\% 25,8^{\prime} \mathrm{i}$ genel sağlık hizmetlerine ulaşımda sorun yaşadığını belirtmiştir. Benzer oranlar konaklama imkânlarında da yaklaşık olarak aynı seyretmektedir. Kalacak yer bulmada sorun yaşayanların oranı $\% 29,7$ 'dir ki bu oran yabancı bir ülkeye ilk defa gelen öğrenciler için görece düşük bir orandır. Konaklama imkânına erişimi olan öğrencilerin \%25,1'i kaldıkları yerden memnun olmamakla birlikte $\% 69,1$ 'i eviyle üniversite arasındaki ulaşımın kolay olmasından memnundur. Böylece sağllk, konut ve eğitime erişebilirlikte uluslararası öğrencilere yönelik gettolaşma benzeri bir ayrımcılığın olduğundan ya da altyapı yetersizliğinden kaynaklı bir sosyalleşme 
probleminden bahsetmek için eldeki veriler yetersiz görünmektedir. Bunun yanında uluslararası öğrencilerin sosyalleşme konusunda yaşadıkları sorunlar arasında öne çıkan problemler; sıla hasreti, ekonomik durum, Türklerle zaman geçirme ve arkadaşlık kurma sayılabilir. Kendisini Türkiye'de yalnız hisseden öğrencilerin oranı \%33,5 ile görece düşüktür. Özellikle zaman geçtikçe yalnızlık hissi de azalmaktadır. Bir yıldan az zamandır Türkiye'de ikamet edenlerin \%37,7'si kendini yalnız hissederken beş yılı aşkın süredir bulunanların sadece \%23'ü kendilerini yalnız hissetmektedir. Kendini yalnız hissedenlerin geldikleri coğrafyaya bakıldığında \%45,9 ile Ortadoğu, \%37,5 ile Afrika ve \%33,5 ile Asyalıların en yüksek oranlara sahip olduğu görülmektedir. Avrupalıların \%5,9’u ve Balkanlardan gelenlerin \%18,1'i kendilerini yalnız hissetmektedir. Tablo 7'den okunabileceği üzere Türkçe diline olan hâkimiyet düzeyi arttıkça yalnızlık hissi azalmakta, dilin yetersizliği ise beraberinde izole olmayı getirebilmektedir. Sosyalleşme açısından önemli olan diğer bir sorun öğrencilerin ekonomik durumudur. $\mathrm{Bu}$ bakımdan ekonomik durumu meydana getirin bileşenler aşağıda (Tablo 9) verilmiştir. 
Tablo 9: Uluslararası Öğrencilerin Ekonomik Durumunu Meydana Getiren Bileșenler

\begin{tabular}{|c|c|c|c|c|c|}
\hline & 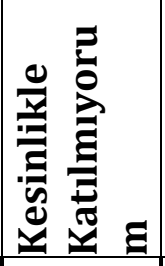 &  & $\begin{array}{l}y \\
\vdots \\
\vdots \\
\vdots\end{array}$ & 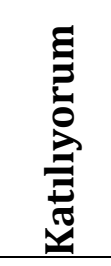 & 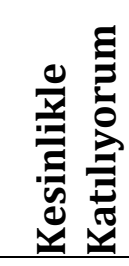 \\
\hline $\begin{array}{l}\text { Gelirim Türkiye'de } \\
\text { Okumak İçin Yeterlidir }\end{array}$ & 11,7 & 28 & 19,3 & 34,5 & 6,5 \\
\hline $\begin{array}{l}\text { Gelirim Sosyal/Kültürel } \\
\text { Faaliyetlerim İçin } \\
\text { Yeterlidir }\end{array}$ & 10,3 & 27,4 & 26,1 & 31 & 5,2 \\
\hline $\begin{array}{l}\text { Geçimimi Sağlamak İ çin } \\
\text { Çalışmak Zorundayım }\end{array}$ & 9,2 & 28,3 & 24,2 & 26,4 & 12 \\
\hline $\begin{array}{l}\text { Üniversitem Bana } \\
\text { Çalıșma İmkânı Sunar }\end{array}$ & 13,9 & 22,8 & 39,4 & 19,3 & 4,6 \\
\hline $\begin{array}{l}\text { Türkiye'de Yeterli } \\
\text { Beslenebiliyorum }\end{array}$ & 6,5 & 16,8 & 16,8 & 47 & 12,8 \\
\hline
\end{tabular}

Tablo 9 incelendiği zaman katılımclların gelir düzeyleri konusunda verdikleri olumlu ve olumsuz yanitların hemen hemen birbirine yakın oranlarda olduğu görülmektedir. Örneğin, gelirinin Türkiye'de okumak için yeterli olduğunu düşünenler \%41 ve aksini düșünenler \%39,7 oranındadır. Aynı şekilde gelirinin bir sosyal ya da kültürel aktivitede bulunmak için yeterli olduğunu varsayanlar $\% 36,2$ ve yetersiz olduğu kanaatinde bulunanlar ise $\% 37,7^{\prime}$ lik kesimi oluşturmaktadır. Öğrencilerin \%37,5’i geçimini sağlamak için çalışmak zorundayken, \%38,4'ünün geliri okuması için yeterlidir. Gelir konusundaki oranlarm bu denli paralellik arz etmesi uluslararası öğrencilerin geçimlerini sınırda yaşadıklarını göstermektedir. Örneğin, Türkiye'de öğrenim gören öğrencilerin $\% 23,3$ 'ü yeterli beslendiğini düşünmemekte, yani her dört öğrenciden biri dengeli beslenememektedir.

Yıllar içerisinde ise öğrencilerin temel geçim kaynaklarını 
kamusal kaynaklardan özel kaynaklara doğru yönelttikleri gözükmektedir. Türkiye'de bir yıldan az ikamet edenlerin \%61,3'ü, bir ila üç yıl arasında kalanların \%58,1', üç ila beş yıl arasında bulunanların \%56,2'si ve beş yıldan fazla süredir yaşayanların \%42,3'ünün geçimlerini kamusal kaynaklardan sağladıkları gözükmektedir. Bu durum bir yandan sürenin uzamasıyla birlikte bursların azalması ya da kesilmesinin getirdiği bir durumken bir yandan da ülkeye adaptasyonla birlikte özel sektörde kendilerine iş bulabilmekten kaynaklı bir değişime işaret etmektedir. Temel geçim kaynağının menşei aynı zamanda öğrencilerin konaklama birimlerinin seçiminde de önemli rol oynamaktadır. Katılımcılardan KYK yurtlarını tercih edenlerin \%82,4'ü temel geçimini kamudan sağlarken, özel yurtları tercih edenlerin \%49,3'ü ve bir evde kalanların \%89,7'si geçimini özel kaynaklardan sağlamaktadır.

Öğrencilerin kaldıkları yerin niteliği onların sosyalleşmesini etkilemektedir. Örneğin; KYK yurtlarında konaklayanların \%70,3’ü sıla hasreti çekerken özel yurtta kalanların \%58,9'u ve bir evde yaşayanların \%56,4'ü memleket özlemi içerisindedir. Özel yurtta kalanların \%75,3'ü iyi Türkçe konuştuklarını düşünürken, KYK'da kalanlarda bu oran \%55,8 ve bir evde yaşayanlarda \%48,3'tür. Türkçe konuşmanın derslerine yönelik başarı hissini arttırdığı ve yalnızlık hissini azalttığı daha önce gösterilmiştir. Aynı şekilde sosyalleşmenin diğer ayırt edici bir adımını oluşturan arkadaş edinme konusunda da Türkçe konuşmak önemli rol oynamaktadır. KYK'da konaklayan öğrencilerin \%42,2'si ve özel yurtta kalanların \%39,8'i Türk öğrencilerle daha çok vakit geçirmektedir. Türk öğrencilerle vakit geçirme oranlarının Türk kültür havzasıyla ilgili olduğu görülmektedir. Balkanlardan gelenlerin \%50'si, Asyalıların \%44,5'i ve Ortadoğu menşeililerin \%41,7'si Türk öğrencilerle daha çok vakit geçirdiğini belirtirken bu oranlar Afrika kökenlilerde \%37,5 ve Avrupalılarda \%35,3'e gerilemektedir. Benzer şekilde Türk kültürünün kendi kültürlerine yakınlığı konusunda Balkanlardan gelenlerin \%81,8'i, Asyalıların \%56,4'ü ve Ortadoğu kökenlilerin 
$\% 50$ 'si hemfikirdir. Bu durumda Balkanlardan gelenlerde kültürün, Ortadoğu kökenlilerde dinin ve Asyalılarda dilin kültürel birleștirici unsur oluşturduğu söylenebilir. Ancak bu bağdaştırmalar mutlak değildir. Modernleşmenin küreselleşmeyle birleşmesi milletler üzerinde homojenleștirici bir etki yapmıştır. Keza Avrupalıların da $\% 58,9$ 'u ve Afrika kökenlilerinde $\% 51,8$ 'i Türk kültürünü kendi kültürlerine yakın bulmaktadır. Genele bakıldığında katılımcların $\% 56$ 'sı Türk kültürünü kendi kültürlerine yakın bulurken $\% 31,8$ 'i ise uzak bulmaktadır. Uluslararası öğrencilerin sadece \%26,6'sı arkadaşlık kurmakta zorlandığını ve $\% 14,2$ 'si yabancılarla etkinlikte bulunmayacağını belirtirken Türk öğrencilerle zaman geçirme oranı $\% 41,8$ 'de kalmaktadır. Bunun sebepleri arasında dil, din ve kültür gibi faktör bulunmakla birlikte öğrencilerin birbirleriyle derinlemesine etkileşime girecekleri ortamların kısmen yetersiz olması da yer almaktadır. Üniversitede sportif etkinlikleri yeterli bulanların oranı $\% 40,5$ ve kültürel etkinlikleri yeterli bulanların oranı ise sadece $\% 35,6$ 'dır. Uyumun ve sosyalleşmenin önemli bir ayağını oluşturan yaşanılan ülkedeki politik gelişmeler konusundaki iletişim oranları da oldukça düşüktür. Arkadaşlarıyla Türk siyaseti hakkında konuşurum diyenlerin oranı \%32,6'dır. Sportif, kültürel ve politik iletişimin düşük olmasının uluslararası öğrencilerin Türkiye'deki eğitim, kültür ve sosyal hayata uyumunu zorlaştırdığı söylenebilir.

\section{Sonuç}

Çalışmanın başında öğrencilerin Türkiye'yi tercih sebepleri arasında tarihsel, dilsel ve kültürel faktörlerle birlikte jeopolitik faktörlerin etkili olabileceği söylenmişti. Bu bağlamda yaşanan sorunlara bakıldığında bu alanlarda ciddi bir sorun alanının tespit edilemediği, yaşanan sorunların daha ziyade akademi ve sosyalleşme gibi sistematik meseleler olduğu söylenebilir. Yaşanan sorunlar; oryantasyon eksikliği, Türklerle iletişimde sorunlar, eğitimin 
niteliğine dair endișe, ekonomik durum ve sıla hasreti gibi başlıklar altında toplanabilir. Oryantasyon eksikliği birçok çalışmada dile getirilmesine rağmen halen bu alanda yeterli adımların atılmadığı ve öğrencilerin kendi imkânları ile bu sorunu aştığı, bu durumun da yaşanılan sorunları arttırdığı söylenmelidir. $\mathrm{Bu}$ anlamda atılacak adımlar öğrencilerin üniversite içi hareketliliğini ve sosyalleşme imkânlarını arttıracaktır. Öğrencilerin dil seviyelerini yüksek görmeleri ve okuma, yazma, konuşma, anlama gibi noktalarda kendilerini yeterli görmeleri Türklerle iletişimde salt dilsel bir sorun yaşanmadığını göstermektedir. Bu durum kendini yabancı hissetme duygusu ile beraber düşünülebilir. $\mathrm{Bu}$ hissin bireysel bir boyutu olabileceği gibi toplumsal bir boyutu da bulunmaktadır. Yine kendilerini dilsel olarak yeterli hissedişleri ve eğitim hususunda belirttikleri, bunun yanında üniversitenin kültürel ve sportif faaliyetlerinin yetersizliği konuları birlikte ele alındığında eğitimin niteliğinden duyulan memnuniyetsizliği ortaya koymaktadır. Ayrıca ekonomik durumda yaşanan sorunlar ve sıla hasreti çeken öğrencilerin varlığı da eğitimin ve sosyal hayatın niteliğini belirleyen temel sorun alanlarını oluşturmaktadır.

Çalışmada tespit edilen sorun alanlarının literatürde karşılaşılan sorunlarla da örtüştüğü söylenilmelidir. Oryantasyon, iletişim, eğitim kalitesi, ekonomik imkânlar gibi faktörlerde yaşanan sorunlar öğrenci hareketliliğini zorlaştıran faktörler arasındadır. Özellikle bu imkânların sözlü olarak diğer öğrencilere deneyim yoluyla aktarıldığı düşünüldüğünde, bunun uluslararası öğrenci hareketliliğini etkileyen bireysel faktörler açısından önemli olduğu vurgulanmalıdır. Aynı şekilde sorunların sürekliliği Sakarya Üniversitesi'nin uluslararası öğrenci hareketliliğini etkileme potansiyelini de barındırmaktadır. 
Uluslararası Öğrencilerin Akademik ve Sosyal Yaşamlarında Karşılaştıkları Sorunlar Üzerine İnceleme

\section{Kaynakça}

Alagöz, Sevda Başaran \& Geçkil, Tahsin. "Yabancı Uyruklu Üniversite Öğrencilerinin Sorunlarının İncelenmesi: Konya İli Örneği”. Anadolu Hemşirelik ve Sağlık Bilimleri Dergisi 20/4 (2017), 279-285.

Can, Ahmet. An Examination of the Relationship Between Adjustment Problems, Homesickness, Perceived Discrimination and Psychological Wellbeing among International Students. Ohio: Ohio University, Doktora Tezi, 2015.

Crano, Suellen L. \& Crano William D. "A Measure of Adjustment Strain in International Students". Journal of Cross-Cultural Psychology, 24/3 (1993), 267-283.

Çetinsaya, Gökhan. Büyüme, Kalite, Uluslararasılaşma: Türkiye Yükseköğretimi İçin Bir Yol Haritası. Eskişehir: Anadolu Üniversitesi Basımevi Müdürlüğü, Genişletilmiş 2.Baskı, 2014.

Dawson, Catherine. A Practical Guide to Research Methods. Oxford: How to books, Third Edition, 2007.

De Wit Hans vd.. "International student mobility”. Perspectives: Policy and Practice in Higher Education 17/1 (2013), 17-23.

DeVors, J. “International Students Struggles”. Erişim: 21 Eylül 2019. https://www.researchgate.net/publication/320765245_Inter national_Student_Struggles

Fred J Galloway \& John R Jenkins. “The Adjustment Problems Facedby International Students in the United States: A Comparison of International Students and Administrative Perceptions at Two Private, Religiously Affiliated Universities". NASPA Journal, 42/2 (2005), 175-187. 
Gebhard, J. G. “International students' adjustment problems and behaviors”. Journal of International Students 2(2) (2012), 184193.

Gökyer, Necmi. "Yabancı Uyruklu Üniversite Öğrencilerinin

Psikolojik Uyumu”, Yükseköğretim ve Bilim Dergisi 7/1 (2017), 98-108.

Güçlü, Nezahat. "Yabancı Öğrencilerin Uyum Problemleri”.

Hacettepe Üniversitesi Eğitim Fakültesi Dergisi 12 (1996), 101110.

Gürbüz, Rabia \& Güleç İsmail. “Türkiye’de Eğitim Gören Yabancı Öğrencilerin Türkçeye İlişkin Görüşleri: Sakarya Üniversitesi Örneği". Sakarya University Journal of Education 6/2 (2016), 141-153.

Harunoğulları, M. vd.. “Türkiye'deki Suriyeli Üniversite Öğrencileri ile İlgili Bir Durum Tespiti: Osmaniye Korkut Ata Üniversitesi Örneği”. Afyon Kocatepe Üniversitesi Sosyal Bilimler Dergisi 21/3 (2019), 816-837.

Hellstên, Meeri \& Prescott Anne. "Learning at University: The International Student Experience". International Education Journal 5/3 (2004), 344-351.

Hobsons. "Global International Student Survey 2017: The changing Dynamics of international student recruitment". Erişim: 21 Eylül 2019.

https://www.hobsons.com/res/Whitepapers/Hobsons_Insigh ts2017_Global_Web.pdf

Kılıçlar, Arzu vd.. “Türk Dünyasından Gelen Öğrencilerin Yaşadıkları Sorunların Akademik Başarılarına Etkisi: Turizm Öğrencileri 
Örneği”. Bilig-Türk Dünyası Sosyal Bilimler Dergisi 61 (2012), 157-172.

Kıroğlu, Kasım vd.. “Türkiye'de Öğrenim Gören Yabancı Uyruklu Lisans Öğrencilerinin Sosyo-Kültürel ve Ekonomik Sorunları". Mersin Üniversitesi Eğitim Fakültesi Dergisi 6/2 (2010), 26-39.

Kondakçı, Yaşar. "Student mobility reviewed: attraction and satisfaction of international students in Turkey". High Educ 62 (2011), 573-592.

Kumcağız, Hatice vd.. “Ondokuz Mayıs Üniversitesi'ndeki Yabancı Uyruklu Öğrencilerin Sınıf Düzeylerine Göre Yaşadıkları Sorunlar". OMÜ Eğt. Fak. Dergisi 35/2 (2016), 37-50.

Kusek, Weronika A. "Evaluating the Struggles with International Students and Local Community Participation". Journal of International Students 5/2 (2015), 121-131.

Malaklolunthu, Suseela \& Selan Poovaikarasi Sateyen. "Adjustment problems among international students in Malaysian private higher education institutions" Procedia Social and Behavioral Sciences 15 (2011), 833-837.

McMahon, M.E. "Higher Education in a World Market. An Historical Look at the Global Context of International Study", Higher Education 24/4 (1992), 465-282.

OECD "Education at a Glance 2018: OECD Indicators". Paris:OECD Publishing. Erişim: 01 Mayıs 2019 http://dx.doi.org/10.1787/eag-2018-en

Open Doors "Report on International Education Exchange". Erişim: 01 Mayıs 2019 https://www.iie.org/Research-andInsights/Open-Doors/Open-Doors-2018-Media-Information 
Özoğlu Murat vd.. "Factors influencing international students' choice to study in Turkey and challenges they experience in Turkey", Research in Comparative \& International Education 10/2 (2015), 223-237.

Paksoy, Mustafa H. vd.. “Türkiye'de Yüksek Öğrenim Gören Yabancı Uyruklu Öğrencilerin Sosyal Sorunları: Gap Bölgesi Üniversiteleri Örneği”. Kahramanmaraş Sütçü imam Üniversitesi Íktisadi ve İdari Bilimler Fakültesi Dergisi 2/2 (2012), 85-94

Punch, Keith F. Sosyal Araştırmalara Giriş: Nicel ve Nitel Yaklaşımlar, çev. Dursun Bayrak, H.Bader Arslan, Zeynep Akyüz. Ankara: Siyasal Kitapevi, 4.Baskı, 2016.

SAU. "Yabancı Öğrenciler”. Erişim: 21 Eylül 2019. http://about.sakarya.edu.tr/tr/Ogrenciler/Ogrenciler/Yabanc iOgrenciler

Seydi, R. A. “Türkiye'nin Suriyeli SığınmacılarınEğitim Sorununun Çözümüne Yönelik İzlediği Politikalar”. SDÜ Fen Edebiyat Fakültesi Sosyal Bilimler Dergisi 31 (2014), 267-305.

Sezgin, A. A. \& Yolcu. T. “Göç İle Gelen Uluslararası Öğrencilerin Sosyal Uyum Ve Toplumsal Kabul Süreci”. Humanitas 4/7 (2016), 417-436.

Sungur, M. A. vd.. "Düzce Üniversitesinde Yükseköğrenim Gören Yabancı Uyruklu Öğrencilerin Yaşam Doyumları ve Sosyal Uyumlarını Etkileyen Faktörler" Düzce Üniversitesi Sağlık Bilimleri Enstitüsü Dergisi 6/2 (2016), 101-109.

Şahin, Münir \& Demirtaş, Hasan. “Üniversitelerde Yabancı Uyruklu Öğrencilerin Akademik Başarı Düzeyleri, Yaşadıkları Sorunlar Ve Çözüm Önerileri”. Milli Eğitim 204 (2014), 88-113. 
Taşar, H. Hüseyin. “Türkiye'deki Suriyeli Mültecilerin Yükseköğretim Sorunları: Adıyaman Üniversitesi Örneği". Adlyaman Üniversitesi Sosyal Bilimler Enstitüsü Dergisi 11/31 (2019), 160-187.

Travel.state.gov. "Court Order on Presidential Proclamation". Erişim: 20 Eylül 2019. https://travel.state.gov/content/travel/en/us-visas/visainformation-resources/presidential-proclamationarchive/2017-12-04-Presidential-Proclamation.html

Usta, Sefa vd.. "Yabancı Uyruklu Öğrencilerin Kente ve Üniversiteye Uyumu: Karaman İli Örneği”. Yükseköğretim ve Bilim Dergisi 7/3 (2017), 565-577.

Wang, Jing. "A Study of Resiliency Characteristics in the Adjustment of International Graduate Students at American Universities". Journal of Studies in International Education 13/1(2009),2245.

Yardımcıoğlu, Fatih vd.. "Uluslararası Öğrencilerin Sosyo-Ekonomik Problemleri ve Çözüm Önerileri (Sakarya Üniversitesi Örneği)". Akademik İncelemeler Dergisi 12/1 (2017), 203-254.

Yazıcıoğlu, Yahşi \& Erdoğan, Samiye. SPSS Uygulamalı Bilimsel Araştırma Yöntemleri. Ankara: Detay Yayıncılık, 2004.

YÖK, “Öğrenci İstatistikleri”, Erişim: 20 Eylül 2019, https://istatistik.yok.gov.tr/

Zavalsız, Y.Sinan \& Gündağ Emine. "Yabancı Uyruklu Öğrencilerin Sosyo-Kültürel Entegrasyonu (Karabük Üniversitesi Örneği)". İnsan ve Toplum Bilimleri Araştırmaları Dergisi 6/5 (2017), 3168-3192. 
Fikret TOPAL-Soner TAUSCHER 